\title{
Bioremediation of petroleum refinery effluent by Planococcus halophilus
}

\author{
R. Vennila * and V. Kannan \\ Centre for Advanced Study in Botany, Guindy Campus, University of Madras, Chennai 600 025, India.
}

Accepted 8 July, 2010

\begin{abstract}
In the present investigation, Planococcus halophilus was screened for hydrocarbon degradation and bioremediation of refinery effluent. The test organism, $P$. halophilus, showed the capability to utilize kerosene as carbon source in minimal medium. Biological treatment of the refinery effluent with $P$. halophilus reduced the oil and grease and sulphide content to about 91.2 and $28 \%$, respectively, on the 4th day of the incubation. The present work defined that the test organism $P$. halophilus can be exploited for bioremediation of sites contaminated with hydrocarbons and industrial effluents polluted with hydrocarbons even under adverse conditions.
\end{abstract}

Key words: Kerosene, Planococcus halophilus, bioremediation, parameters, hydrocarbon.

\section{INTRODUCTION}

Large amount of hydrocarbon contaminants are released into environment as a result of human activities. They pose severe, immediate as well as long term ecological and environmental repercussions, since a lot of hydrocarbon components are toxic and persistent in terrestrial and aquatic environments. Physicochemical methods are usually expensive and labour intensive and often involve the risk of spreading pollution because the waste would require disposal elsewhere. A better way would to be to use biodegradation (Abu Bakar Salleh et al., 2003). Planococcus alkanocladisticus isolated from intertidal beach sediment was reported to degrade alkanes (Engelhardt et al., 2001). Hence the present study was taken with the aim of studying the bioremediation of contaminated hypersaline areas using moderately halophilic bacteria, Planococcus halophilus.

\section{MATERIALS AND METHODS}

\section{Sampling of effluents}

Refinery effluent was collected from the effluent pumping station of Chennai Petroleum Corporation Limited, Manali, Chennai and

\footnotetext{
*Corresponding author. E-mail: venn779@gmail.com.
}

stored in cold room $\left(4^{\circ} \mathrm{C}\right)$.

Isolation and identification of Planococcus halophilus

Water sample collected from solar crystallization ponds were serially diluted with sterile sea water and $0.1 \mathrm{ml}$ from $10^{-2}$ and $10^{-3}$ dilution was plated on nutrient agar medium. After $24 \mathrm{~h}$ incubation, the bacterial colonies were counted and identified by morphological and biochemical characteristics. Pure isolates were maintained in slants and sub cultured at an interval of two weeks.

Based on the morphological and biochemical characteristics, the isolate were provisionally identified as $P$. halophilus (grams reaction, +ve; coccus, motility, +ve; catalase, +ve; oxidase, -ve; nitrate reduction, -ve; citrate utilization, -ve; gelatine utilization, +ve; acid/gas production, $+v e$; indole test, -ve; methyl red, -ve).

\section{Biodegradation of kerosene}

The rate of degradation of aliphatic hydrocarbon namely, kerosene was analysed by gas chromatographic analysis. The culture was grown on minimal salts medium $\left(\mathrm{KH}_{2} \mathrm{PO}_{4}, 0.017 \mathrm{~g} / \mathrm{l} ; \mathrm{NH}_{4} \mathrm{Cl}, 0.254 \mathrm{~g} / \mathrm{l}\right.$; $\mathrm{MgSO}_{4}, 0.45 \mathrm{~g} / \mathrm{l} ; \mathrm{CaCl}_{2}, 0.073 \mathrm{~g} / \mathrm{l} ; \mathrm{Na}_{2} \mathrm{HPO}_{4}, 0.017 \mathrm{~g} / \mathrm{l}$; sea water, 1000 $\mathrm{ml})$ amended with kerosene $(0.1 \% \mathrm{v} / \mathrm{v})$ at $37^{\circ} \mathrm{C}$.

After $48 \mathrm{~h}$ of incubation, the culture filtrate was extracted with dichloromethane and concentrated under vacuum and the concentrated residue was analysed on gas chromatography (Instrument Model 8500, Detector-FID, Detector temperature $-250^{\circ} \mathrm{C}$, Detector range - high, column - $50 \mathrm{~m} \times 0.22 \mathrm{~mm}$ fused silica). Pure kerosene served as control. The reduction in the specific absorption peak height of compounds confirms the degradation of aliphatic 
hydrocarbon.

\section{Biodegradation of effluents}

$250 \mathrm{ml}$ of the raw effluent was taken into a $500 \mathrm{ml}$ Erlenmeyer flask and inoculated with $24 \mathrm{~h}$ old culture of $P$. halophilus and incubated on a shaker with $250 \mathrm{rpm}$ for 4 days at $35 \pm 2^{\circ} \mathrm{C}$. Nitrogen source was supplemented as potassium nitrate at $1 \mathrm{gl}^{-1}$. After incubation, the following analyses were made: Total suspended solids, oil and grease, sulphide, chemical oxygen demand (COD) and biological oxygen demand (BOD). This experiment was conducted in triplicates.

\section{Estimation of total suspended solids}

A known volume of well mixed effluent sample was taken into the cell and the reading was noted at $630 \mathrm{~nm}$. Distilled water was used as a blank in a clean sample cell.

\section{Estimation of oil and grease}

Oil and grease was estimated before and after treatment of the effluent sample. To the clean separating funnel, $350 \mathrm{ml}$ of effluent sample was taken. $2 \mathrm{ml}$ of concentrated sulphuric acid was added slowly followed by $350 \mathrm{ml}$ of chloroform. The funnel was inverted after stoppering and the fumes were let out after shaking. The two layers were allowed to separate. Finally, chloroform was extracted into the clean flask and was read in a spectrophotometer at $950 \mathrm{~nm}$. Fresh chloroform was taken as a blank.

\section{Estimation of sulphide}

Exactly $25 \mathrm{ml}$ of diluted sample was taken in a clean nessler cylinder. $1 \mathrm{ml}$ of sulphide 1 and 2 reagents were added to the sample and shaken well. After $5 \mathrm{~min}$ of incubation (at room temperature, $37^{\circ} \mathrm{C}$ ), sample was read in the spectrophotometer at $690 \mathrm{~nm}$ against distilled water as a blank.

\section{Estimation of COD}

Exactly $0.2 \mathrm{ml}$ of sample was taken into the COD digestion vial and refluxed for $2 \mathrm{~h}$ in the digester. After $2 \mathrm{~h}$, the vial was taken out and cooled to room temperature and measured in spectrophotometer at $435 \mathrm{~nm}$. For blank, $2 \mathrm{ml}$ of distilled water was used in the plate of the sample.

\section{Estimation of BOD}

Distilled water was aerated for minimum of 4 to $5 \mathrm{~h}$. $1 \mathrm{ml} / \mathrm{l}$ each of phosphate buffer, magnesium sulphate, calcium chloride, ferric chloride and $0.5 \mathrm{ml} / \mathrm{l}$ sewage feed was added to the aerated distilled water, and stirred very slowly so that no air bubbles are formed.

The $2 \mathrm{ml}$ effluent sample was diluted with $300 \mathrm{ml}$ of well aerated distilled water and transferred into the BOD bottles up to the neck. One set was kept in the incubator for final titration for 3 days at $37^{\circ} \mathrm{C}$. To the initial and final titration, $2 \mathrm{ml}$ of manganeous sulphate solution and $2 \mathrm{ml}$ of alkali azide solution was added to fill up the BOD bottle. A glass stopper was put and shaken well. The precipitate formed was allowed to settle. $2 \mathrm{ml}$ of concentrated sulphuric acid was added slowly and shaken well again. $203 \mathrm{ml}$ was taken in a conical flask and titrated against $0.025 \mathrm{~N}$ sodium thio sulphate using starch as an indicator. One blank estimation was done with the aerated distilled water in BOD bottle simultaneously.

$\mathrm{BOD}(\mathrm{mg} / \mathrm{l})=(\mathrm{D} 1-\mathrm{D} 2) \times$ dilution factor

Where, D1 = Dissolved oxygen in $\mathrm{mg} / \mathrm{l}$ of diluted sample immediately after preparation; D2 = dissolved oxygen in $\mathrm{mg} / \mathrm{l}$ of diluted sample after 3 days of incubation.

\section{RESULTS AND DISCUSSION}

In Figure 1, the growth of $P$. halophilus on nutrient broth is presented. When inoculated in minimal salts medium amended with kerosene (1\%), the test organism showed capability to utilize the hydrocarbon as sole carbon source. The test organism showed good growth with kerosene compared to glucose as sole carbon sources (Figure 2). The test organism is able to degrade kerosene, which is well proved by the peak reduction of hydrocarbon recorded in the extract of culture filtrate of the test organism analysed by gas chromatography (Figure 3 ).

As the test organism showed good degradation potential against kerosene, its ability to remediate refinery effluent was tested with effluents from Chennai Petroleum Corporation Limited (CPCL), India. The characteristics of refinery effluent prior to treatment and after treatment with $P$. halophilus are presented in Table 1 and Figure 4.

The degradation of hydrocarbon by the test organism in the present study is well proved by gas chromatographic analysis and through growth of test organism on media amended with hydrocarbon as sole carbon source. Though halophilic archaea are well known for their stable enzymes not much has been done towards exploiting them for biotechnological applications. Hence we attempted to use $P$. halophilus for hydrocarbon degradation and also for remediation of petroleum refinery effluent in which we have been successful. Though attempts were made to study the hydrocarbon degradation in hypersaline environments since 1978 (Ward and Brock, 1978) no positive report is available on degradation of hydrocarbon by halophiles. Hydrocarbon-degrading moderate halophiles have been isolated from a variety of environments, including the Great Salt Lake (Ward and Brock, 1978) and Antarctic saline lakes. McMeekin et al. (1993) reported the utilization of a biofilm of a moderately halophilc bacterium isolated from a saltern at the Great Salt Lake, Utah, for the treatment of hypersaline wastewaters containing phenol. Moderate halophiles belonging to the family Halomonadaceae have been isolated from highly saline sites contaminated with the herbicide 2,4dichlorophenoxyacetic acid.

The results of the present study thus clearly proved the capability of $P$. halophilus, a moderate halophile in the degradation of hydrocarbon and it can be suggested that this kind of microbe can be well exploited for bioremediation of refinery effluents and other hydrocarbon contaminated sites in a better way as this microbe can tolerate low water and high salt conditions. 


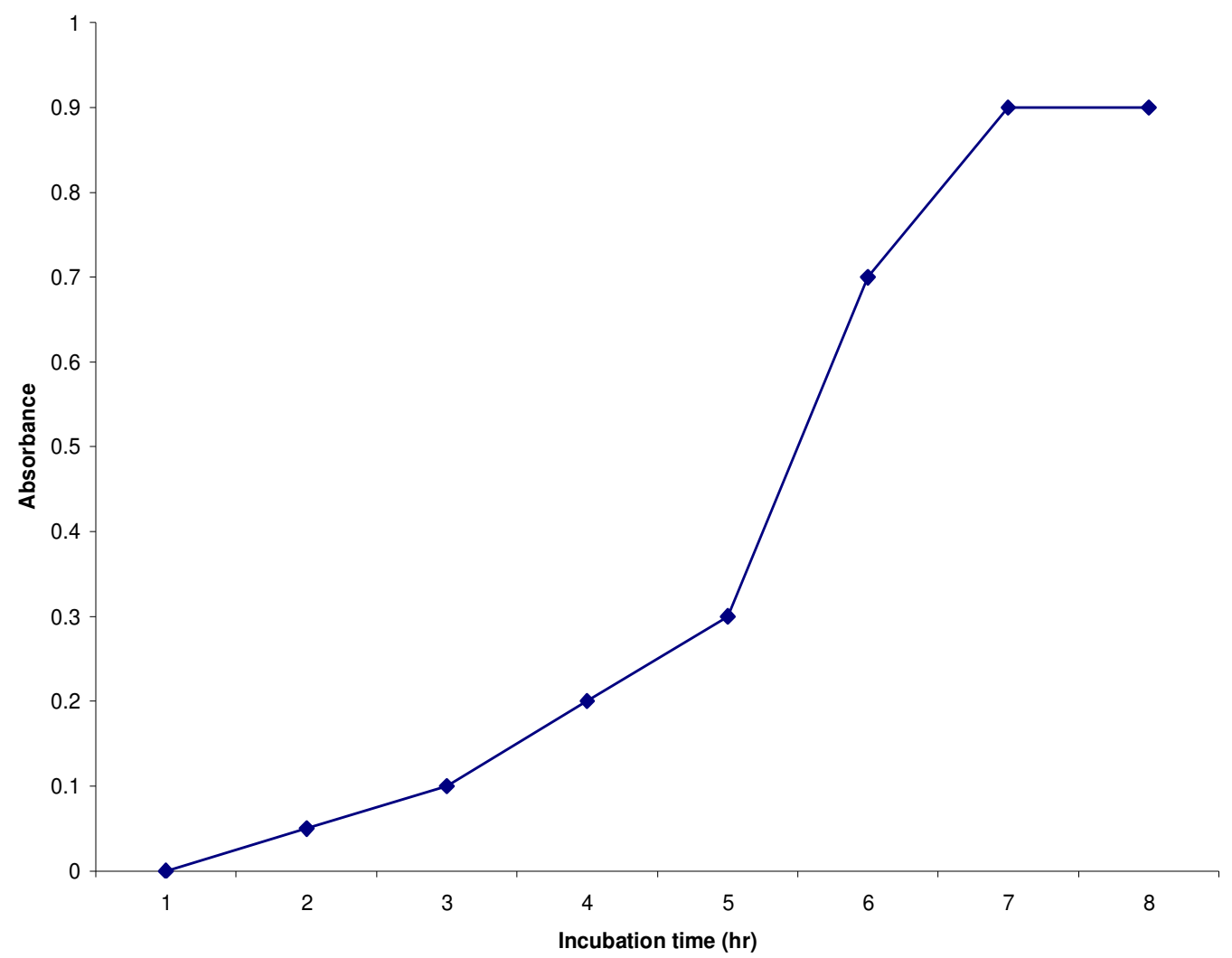

Figure 1. Growth on nutrient broth $P$. halophilus.

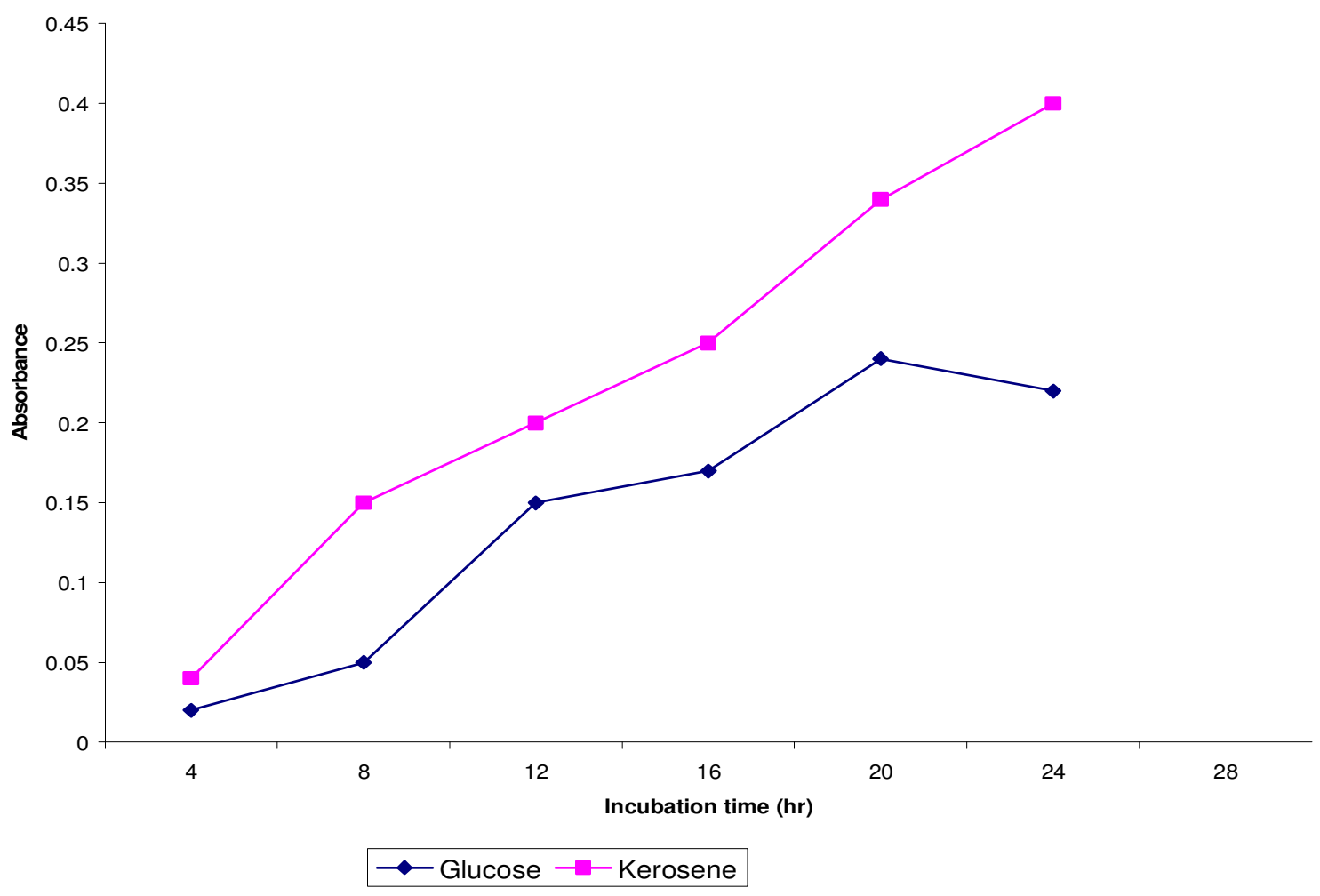

Figure 2. Growth on hydrocarbon amended minimal salts medium Planococcus halophilus 


\section{Kerosene}

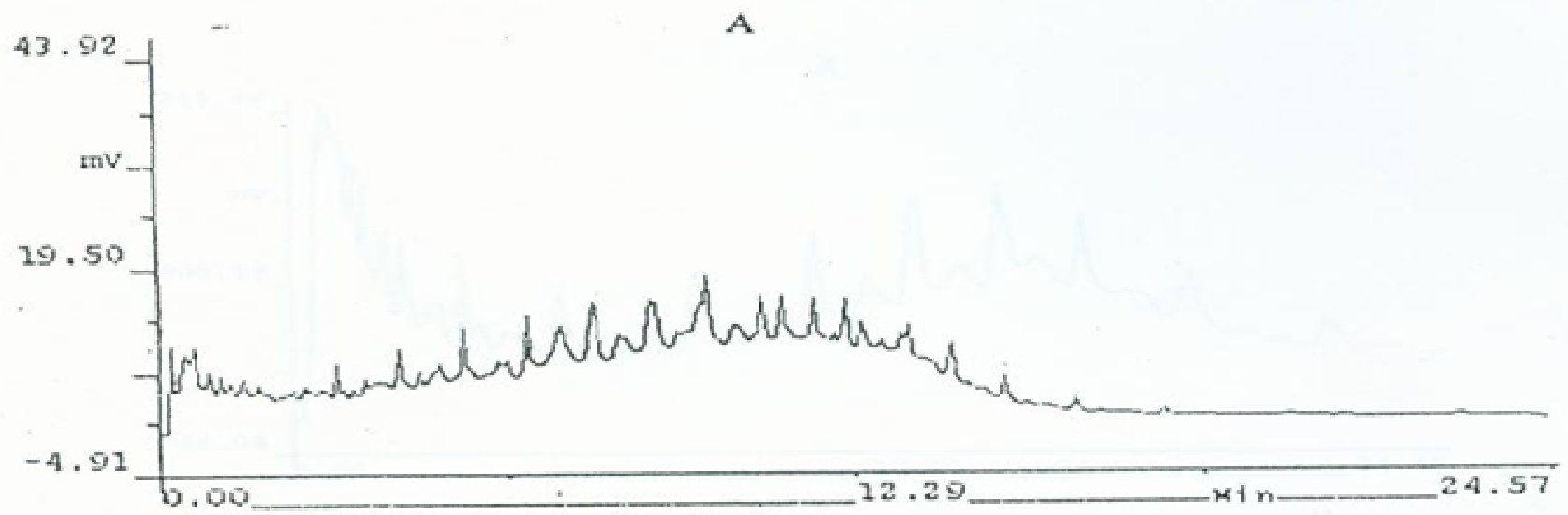

B

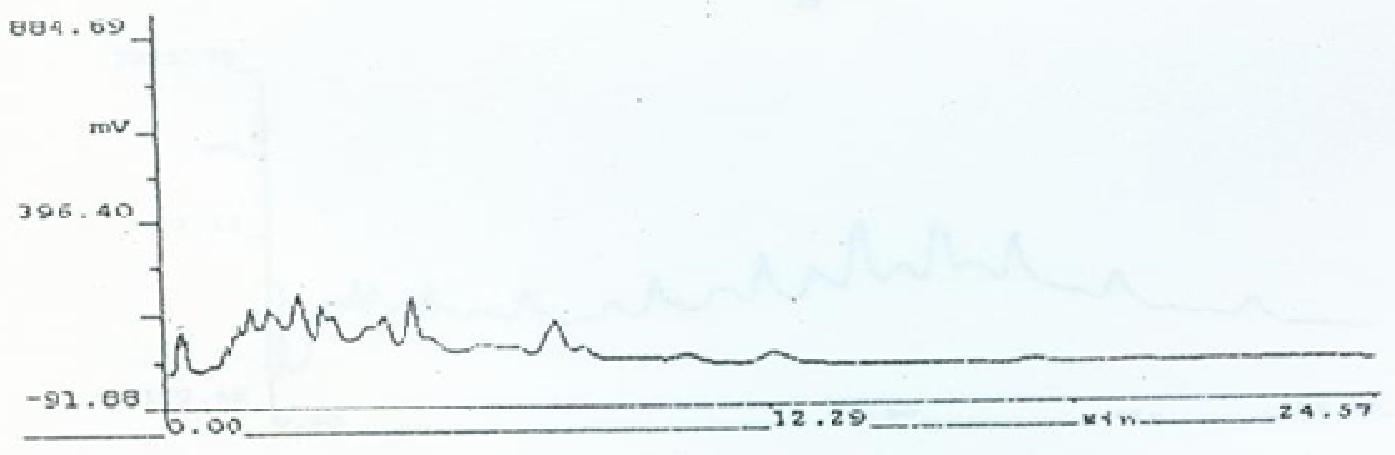
A.
Control
B.
Trented

Figure 3. Degradation of aliphatic hydrocarbon by gas chromatography analysis

Table 1. Characteristics of petroleum refinery effluent.

\begin{tabular}{|l|c|c|}
\hline \multicolumn{1}{|c|}{ Parameters } & Before treatment & After treatment \\
\hline $\mathrm{pH}$ & 8.9 & 8.03 \\
Oil and grease & 150.6 & 7.13 \\
Sulphides $(\mathrm{mg} / \mathrm{l})$ & 7.2 & 5.2 \\
Suspended solids $(\mathrm{mg} / \mathrm{l})$ & 334 & 31 \\
COD $(\mathrm{mg} / \mathrm{l})$ & - & 121 \\
$\mathrm{BOD}(\mathrm{mg} / \mathrm{l})$ & - & 14 \\
\hline
\end{tabular}




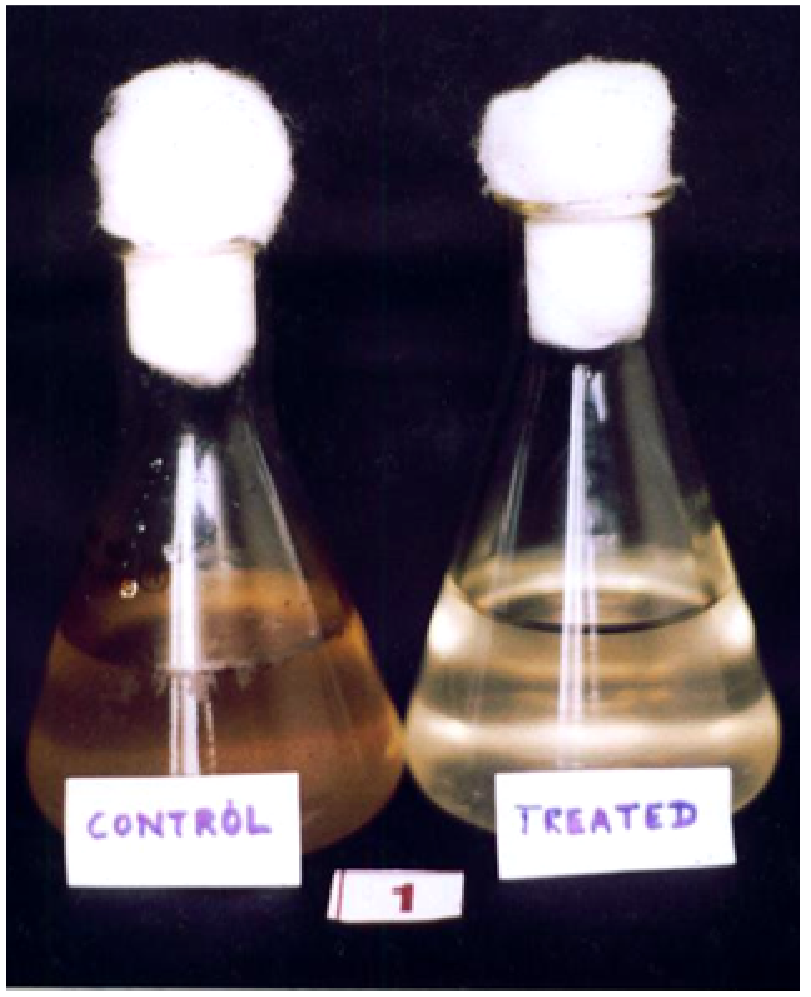

Figure 4. Refinery effluent treatment using $P$. halophilus.

\section{ACKNOWLEDGEMENTS}

Special thanks go to the Chennai Petroleum Corporation Limited (CPCL), Manali, Chennai for allowing me to use their laboratory facilities. I would also like to thank my guide Dr. V. Kannan for his constant help and encouraging words.

\section{REFERENCES}

Abu BS, Farinazleen MG, Raja Noor Zaliha Abd Rahman, Mahiran B. (2003). Bioremediation of Petroleum Hydrocarbon Pollution. Ind. J. Biotechnol. 2(3): 411-425.

Engelhardt MA, Daly K, Swannell RPJ, Head IM. (2001). Isolation and characterization of a novel hydrocarbon-degrading, gram-positive bacterium, isolated from intertidal beach sediment, and description of Planococcus alkanoclasticus sp. nov. J. Appl. Microbiol. 90(2): 237247.

McMeekin TA, Nichols PD, Nichols SD, Juhasz A, Franzmann PD (1993). Biology and biotechnological potential of halotolerant bacteria from Antarctic saline lakes. Experentia, 49: 1042-1046.

Ward DM, Brock TD (1978). Hydrocarbon biodegradation in hypersaline environments. Appl. Environ. Micrbiol. 35: 353-359. 